\title{
Keterampilan Manajerial Kepala Sekolah dalam Meningkatkan Kinerja Guru
}

\author{
Yulekhah Ariyanti \\ Jurusan Manajemen, Fakultas Ekonomi, Universitas Wahid Hasyim \\ Email: yulekhah@unwahas.ac.id
}

\begin{abstract}
Abstrak
Manajerial Kepala sekolah merupakan hal yang harus dilakukan secara terencana dan kontinyu. Tujuan penelitian ini adalah untuk mendiskripsikan manajerial Kepala sekolah dalam meningkatkan kinerja guru Sekolah Menengah Kejuruan Negeri 6 Semarang. Penelitian ini menggunakan metode diskriptif dengan pendekatan kualitatif. Tehnik pengumpulan data di lakukan melalui observasi, wawancara dan dokumentasi. Subyek penelitian adalah Kepala sekolah. Hasil penelitian menunjukkan: (1) Kemampuan manajerial Kepala sekolah dalam menyusun program perencanaan dirumuskan oleh Kepala sekolah dinilai baik. (2) Strategi yang dilakukan Kepala sekolah dalam pelaksanaan kinerja guru, kemampuan profesional guru telah dilakukan antara lain : membimbing guru dalam menyusun perangkat pembelajaran, menerapkan berbagai model pembelajaran, memberikan motivasi, mengikutsertakan guru dalam pelatihan dan memberikan kesempatan guru untuk melanjutkan studi. (3) Proses pembinaan yang dilakukan oleh Kepala sekolah untuk meningkatkan kinerja guru akan tampak adanya perubahan sikap guru guru yang mengarah kepada perubahan yang lebih baik. Kendala yang dihadapi dalam upaya peningkatan kemampuan profesional guru antara lain menyangkut masalah terbatasnya sumber daya manusia dalam peningkatan kemampuan profesional guru.
\end{abstract}

Kata Kunci : Manajerial Kepala Sekolah, Kinerja Guru

\begin{abstract}
Headmaster managerial is one things must be conducted systematically and continuously. The purpose of this study is to discribe the headmaster managerial at state vocational SMK 6 Semarang. This study uses deskriptive qualitative approach, and the data collection tehniques were observations, interviews and documentations. The subjects of the research were Headmaster. The results shows (1) the headmaster's ability in developing planning programis formulated by headmaster in good appraisal. (2) The strategies undertaken by the school headmaster in teacher performance implementation were : guiding teachers in arranging lesson plan, applying teaching model variation, giving motivation, engaging teacher in some trainning activities and refreshment courses and giving the opportunities to the teachers to pursue their study. (3) Coaching process being carried out by the headmaster to improve the teacher performance, will be seen from the teacher changing attitude to be better. The constraints being faced in improving the professional capability of teacher among others are the limitation of the human resources as, held in conjunction to the professional upgrading of teacher.
\end{abstract}

Keywords : Head master managerial, Teacher performance

\section{PENDAHULUAN}

Kemajuan suatu bangsa sangat ditentukan oleh kualitas sumber daya manusia, sedangkan kualitas sumber daya manusia tergantung pada kualitas pendidikan. Peran pendidikan sangat penting untuk menciptakan masyarakat yang cerdas, intelektual, inovatif, demokratis dan berdedikasi. Sebab itulah, pembaharuan pendidikan harus selalu dilakukan demi peningkatan kualitas suatu bangsa.

Berbicara masalah pendidikan formal seperti diungkap dalam Undang-Undang Republik Indonesia Nomor 20 Tahun 2003 tentang Sistem Pendidikan Nasional (Sisdiknas), Pasal 14 menyebutkan; "Jenjang pendidikan formal terdiri atas pendidikan dasar, pendidikan menengah, dan pendidikan tinggi". Dari ketiga jenjang pendidikan tersebut yang akan dikaji lebih mendalam dalam penelitian ini adalah pendidikan menengah, yaitu Sekolah Menengah Kejuruan (SMK) Negeri 6 Semarang. Alasan penelitian dilakukan SMK Negeri 6 Semarang, karena ingin mengetahui lebih jauh keterampilan manajerial Kepala Sekolah dalam meningkatkan kinerja guru. 
Strategi apa yang harus dilakukan oleh Kepala Sekolah melihat kondisi sekolah sebagai lembaga pendidikan formal bertujuan membentuk manusia yang berkepribadian guna mengembangkan intelektual peserta didik dalam rangka mencerdaskan kehidupan bangsa, sehingga manajerial Kepala Sekolah sebagai pendidik harus dapat memberikan bekal ilmu pengetahuan yang dimiliki kepada peserta didik. Disamping berperan sebagai pendidik, Kepala Sekolah juga harus dapat memfungsikan dirinya sebagai seorang manajer.

Kepala Sekolah memiliki peran penting untuk membantu guru dan peserta didik. Dalam keterampilan memanejerial kepemimpinannya, Kepala Sekolah juga harus dapat memahami, mengatasi dan memperbaiki kekurangan yang terjadi di lingkungan sekolah sebagai organisasi yang dipimpinnya. Peran utama Kepala Sekolah adalah sebagai pemimpin, memanejerial dan yang mengendalikan jalannya penyelenggaraan pendidikan, sehingga pendidikan dapat berfungsi sebagai sebuah organisasi transformasi yang mengubah peserta didik kearah yang lebih baik. Hal ini dituntut suatu proses yang berlangsungnya harus secara benar dan terjaga sesuai dengan ketentuan dari tujuan kependidikan itu sendiri, sehingga menjamin terselenggaranya pendidikan di sekolah yang nyaman dan terkendali.

Kepala Sekolah memerlukan keterampilan manajerial yang baik dalam rangka menjamin kualitas agar sesuai dengan tujuan pendidikan. Kepala Sekolah disamping berfungsi sebagai top manager, juga tidak kalah pentingnya berfungsi sebagai pengawas sekolah. Ini dimaksudkan bahwa seorang top manager adalah faktor penentu dalam sukses atau gagalnya suatu organisasi sekolah dan merupakan kunci pembuka suksesnya sebuah organisasi. Seorang manajer yang sukses harus memiliki kemampuan manajerial dan mampu mengelola organisasinya, menciptakan budaya organisasi yang sehat dan nyaman, mampu mengantisipasi perubahan, mengoreksi kelemahankelemahan serta sanggup membawa organisasinya menuju sasaran jangka waktu yang ditetapkan, sehingga guru akan memiliki kepuasan kerja yang ditunjukkan melalui kinerjanya.

Selain itu, Kepala Sekolah harus melakukan pengelolaan dan pembinaan dalam memanajerial sekolah melalui kegiatan administrasi, manajemen dan kepemimpinan yang sangat tergantung pada kebijakan dan strategi Kepala Sekolah. Hal tersebut tidak akan berjalan dengan baik jika seorang Kepala Sekolah tidak memiliki strategi atau cara-cara tertentu yang dapat membangkitkan motivasi, baik kepada guru maupun peserta didik.

Kepala Sekolah sebagai supervisor berfungsi untuk mengawasi, membangun, mengkoreksi dan mencari inisiatif terhadap jalannya seluruh kegiatan pendidikan yang dilaksanakan dilingkungan sekolah yang dipimpinnya. Kepala Sekolah harus melakukan supervisi dan memiliki jiwa pemimpin yang memungkinkan kegiatan operasional dalam bentuk pembelajaran tersebut dapat berlangsung dengan baik. Hal lain dari Kepala Sekolah sebagai supervisor adalah, bahwa Kepala Sekolah berfungsi sebagai pengawas utama, pengontrol tertinggi yang melakukan supervisi dalam menemukan atau mengidentifikasi kemampuan atau ketidakmampuan personil (Wakil Kepala Sekolah, Ketua Jurusan Program, Kepala laboratorium dan Guru) dalam memberikan pelayanan kepada semua komponen warga sekolah, guna meningkatkan kemampuan keahliannya dan mengelola secara lebih efektif untuk memperbaiki situasi proses pembelajaran, agar peserta didik dapat mencapai prestasi yang lebih meningkat.

Disamping itu Kepala Sekolah sebagai pemimpin (leader) pendidikan berfungsi mewujudkan hubungan manusiawi (human relationship) yang harmonis dalam rangka membina dan mengembangkan kerja sama antar personal, agar secara serempak bergerak ke arah pencapaian tujuan melalui kesediaan melaksanakan tugas masing-masing secara efisien dan efektif. Dengan demikian, segala penyelenggaraan pendidikan akan mengarah kepada usaha meningkatkan mutu pendidikan sebagai salah satu kinerja dari para guru dalam melaksanakan tugasnya secara profesional. Hal di atas diperlukan inovasi dan manajerial yang baik dan harus dimiliki oleh seorang Kepala Sekolah agar dapat memberikan motivasi, sehingga sekolah yang dipimpin dan pengelolaannya mengalami peningkatan, baik dari segi kuantitas maupun kualitas dari kelulusan peserta didik, yang didukung oleh guru-guru yang profesional.

Mengingat begitu pentingnya kepemimpinan dan keterampilan manajerial Kepala Sekolah sebagai supervisor dalam pengawasan kinerja guru serta dalam usaha meningkatkan kinerja guru yang lebih baik, tidaklah mudah bagi seorang Kepala Sekolah, sebab kegiatan tersebut berlangsung sebagai proses yang tidak muncul dengan sendirinya. Kepala Sekolah berupaya secara maksimal 
untuk meningkatkan kualitas pendidikan, salah satu caranya adalah dengan memberikan motivasi kepada para pendidik agar memiliki kinerja yang lebih baik. Namun kenyataan menunjukkan bahwa banyak faktor yang dapat mempengaruhi kinerja guru, maka Kepala Sekolah harus mampu memberikan motivasi dan pembinaan yang dapat mengarahkan guru melaksanakan tugasnya secara efektif, sehingga kinerja guru akan meningkat dan lebih baik. Dengan demikian Kepala Sekolah dapat mengadakan perubahan dalam cara berpikir, mengambil strategi kebijakan dan inovasi perubahan yang lebih baik kepada warga sekolah, khususnya pada guru. Dari keberanian tersebut, setidaknya memberikan perhatian dan pengetahuan serta pengalaman kepada para guru, sehingga Kepala Sekolah dapat membantu dan membina guru untuk berkembang secara profesional. Motivasi guru akan tercermin dalam perwujudan kinerja sebagai pribadi, sebagai warga masyarakat, sebagai pegawai dan sebagai pemangku jabatan profesional guru. Kinerja guru lebih difokuskan pada keterampilan manajerial Kepala Sekolah sebagai sebuah ketrampilan dalam upaya peningkatan kualitas pendidikan yang berbasis kompetensi.

Seorang Kepala Sekolah disamping harus mampu melaksanakan proses manajemen yang merujuk pada fungsi-fungsi manajemen, juga dituntut untuk memahami sekaligus menerapkan seluruh substansi kegiatan pendidikan. Kepala Sekolah memegang peran penting dalam penyelenggaraan pendidikan di sekolah, yang diberikan tanggungjawab untuk melakukan pengelolaan secara penuh terhadap pengaturan jalannya roda kependidikan di sekolah yang dipimpinnya, termasuk yang terjadi di SMKNegeri 6 Semarang.

Fenomena yang terjadi pada sebagian guru SMK Negeri 6 Semarang menunjukkan, masih adanya sebagian guru yang melaksanakan tugas pembelajaran hanya sebagai pelaksanaan kewajiban belaka, sehingga terjadi ketidaksesuaian dalam proses pembelajaran, seperti tidak membuat Rencana Pelaksanaan Pembelajaran, menyusun RPP tidak sesuai silabus, mengajar tidak tepat waktu, dan lain sebagainya. Seoalah-olah mereka melaksanakan proses pembelajaran tidak memperhatikan terhadap hasil berupa kualitas pembelajaran, tetapi hanya tugas mengajar sebagai kewajiban seorang pendidik. Ini memberikan makna bahwa kinerja guru kurang maksimal. Kurangnya koordinasi dan kerjasama antara Kepala Sekolah dengan guru, kepedulian dan kebijakan terhadap guru kurang baik serta kurangnya kedisiplinan pada saat proses pembelajaran dikelas yang belum maksimal. Menunjukkan kemampuan para guru dalam menjalankan tugasnya hanya sebagai kewajiban, sehingga kinerja guru kurang maksimal. Bahkan tidak hanya itu saja, bila ditelusuri lebih jauh, dimungkinkan belum maksimalnya kinerja guru ini disebabkan oleh kurangnya motivasi dan dukungan KepalaSekolah.

Situasi dan budaya sekolah seperti itu harus segera dinetralisir agar tidak berkembang lebih jauh, sebab bila tidak segera diselesaikan dikhawatirkan akan semakin menambah dan memperburuk situasi dan kondisi sekolah. Salah satu person yang memiliki tugas dan kewenangan untuk menyelesaikan situasi tersebut adalah Kepala Sekolah. Diharapkan dengan keterampilan dan strategi yang dimiliki oleh Kepala Sekolah, maka akan mampu menyelesaikan setiap permasalahan yang terjadi di sekolah yang dipimpinnya, baik berkaitan dengan situasi dan kondisi sekolah, motivasi guru hingga sampai pada kinerja, sebab bila budaya sekolah tercipta dengan baik dan nyaman, komunikasi antara guru dengan guru, guru dengan peserta didik, bahkan dengan Kepala Sekolah terbangun dengan baik, maka tidak mengherankan bila guru memiliki kepuasan dalam bekerja yang ditunjukkan oleh kinerjanya. Kinerja tersebut ditunjukkan dengan pelaksanaan tugas dan kewajiban sebagai pendidik. Apabila tugas dan kewajiban dilaksanakan secara maksimal, maka secara tidak langsung kinerja guru akan meningkat, yang berakibat pada perolehan prestasi belajar yang dicapai oleh peserta didik meningkat setiap kelulusannya.

Uraian di atas menggambarkan kurang optimalnya Kepala Sekolah yang belum menunjukkan kemampuan dan strateginya dalam keterampilan manajerial pada sekolah yang dipimpinnya. Kualitas kinerja guru yang kurang optimal, mengingat berbagai pertimbangan yang dikaitkan dengan kondisi dan lingkungan sekolah. Masih adanya sebagian guru yang menunjukkan kinerja kurang maksimal, sehingga perlu ada perbaikan demi kualitas pendidikan. Namun apakah keterampilan manajerial yang dimiliki oleh Kepala Sekolah dapat meningkatkan kinerja para guru SMK Negeri 6 Semarang? Hal inilah yang menyebabkan peneliti tertarik untuk mengadakan penelitian tentang "Keterampilan Manajerial Kepala Sekolah Dalam Meningkatkan Kinerja Guru SMK Negeri 6 Semarang". Berdasarkan latar belakang yang telah dikemukakan di atas, maka 
fokus masalah dalam penelitian ini adalah bagaimana keterampilan manajerial Kepala sekolah pada SMK Negeri 6 Semarang.

\section{METODE PENELITIAN}

Desain penelitian adalah kerangka kerja atau rencana untuk melakukan studi yang akan digunakan sebagai pedoman dalam mengumpulkan dan menganalisis data. Berdasarkan persoalan ketrampilan manajerial Kepala Sekolah dan kinerja guru yang ada di SMK Negeri 6 Semarang maka desain penelitian adalah sebagai berikut :

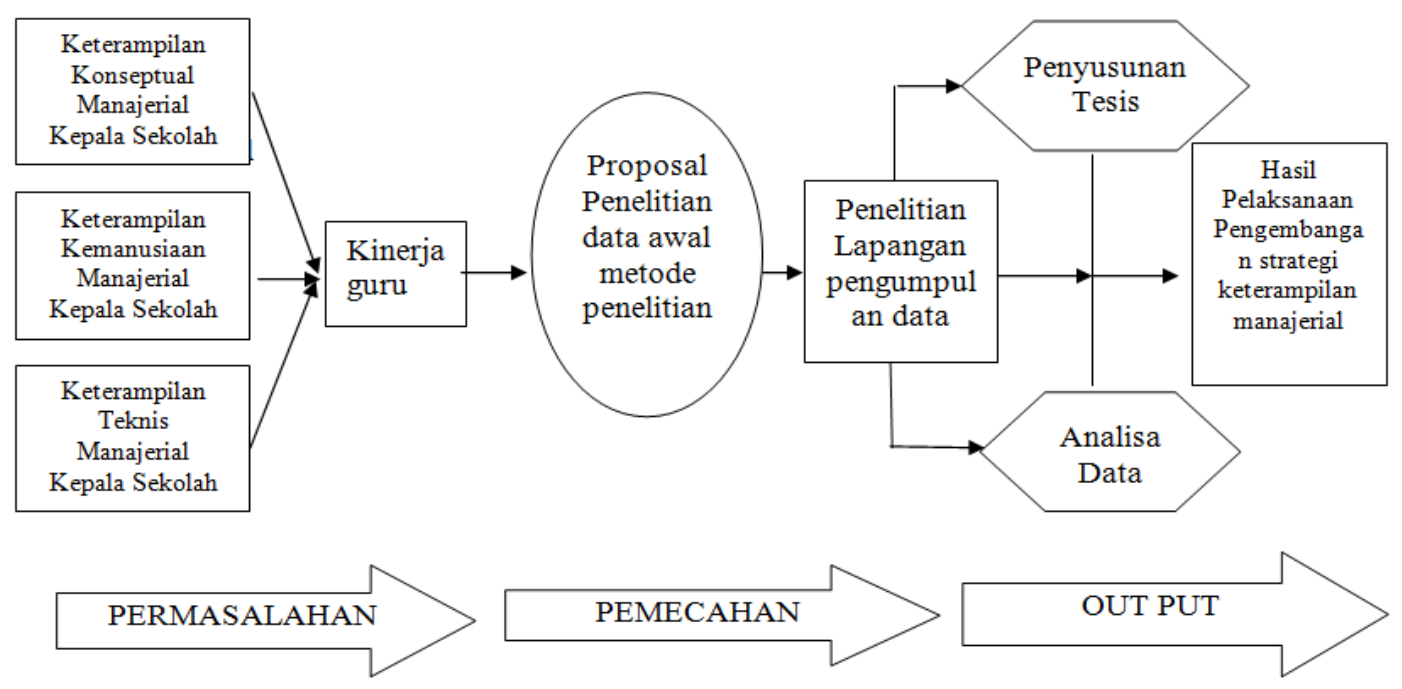

\section{Gambar 1 : Desain Penelitian}

Dalam penelitian ini teknik pemilihan informan menggunakan cuplikan yang bersifat purposive sampling, peneliti cenderung memilih informan yang yang dianggap tahu dan dapat dipercaya seutuhnya sebagai sumber data yang mantap serta mengetahui permasalahan secara mendalam (Sugiono, 2008).

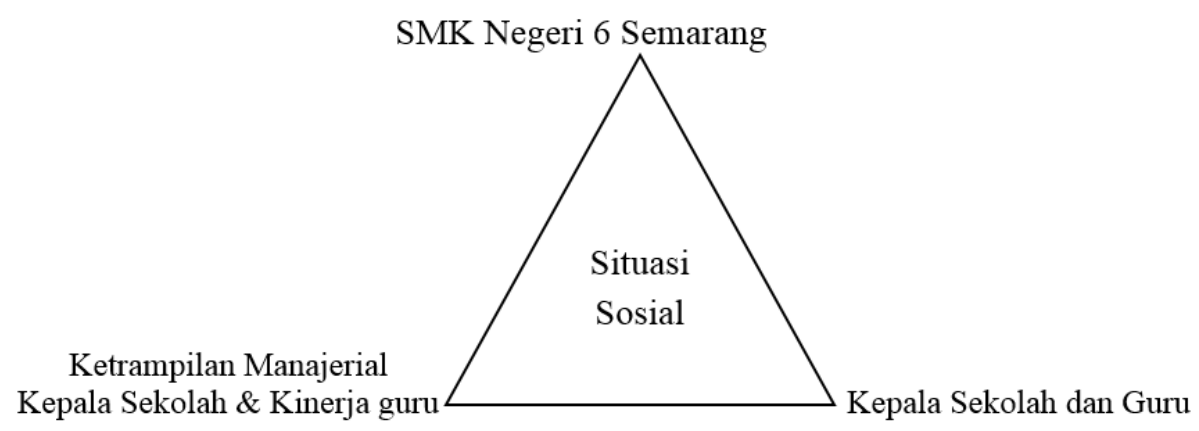

\section{Gambar 2 : Teknik Cuplikan}

Dapat dijelaskan bahwa elemen dari situasi sosial yang dimaksud adalah SMK Negeri 6 Semarang sebagai tempat, aktor adalah guru-guru yang berada di sekolah tersebut dan Kepala Sekolah selaku pelaku dari manajerial Kepala Sekolah dan aktivitas adalah kinerja guru yang dilakukan oleh guru-guru di SMK Negeri 6 Semarang.

Pada SMK Negeri 6 Semarang, yang menjadi informan adalah pengawas, perwakilan orang tua peserta didik / komite, koordinator program keahlian dan semua guru mata pelajaran yang diwakili oleh satu guru, dan masing-masing program keahlian dimana guru tersebut merupakan koordinator. 
Dalam menguji keabsahan suatu data atau memeriksa kebenaran data digunakan cara memperpanjang masa penelitian, pengamatan yang terus menerus, triangulasi, baik triangulasi sumber data maupun triangulasi teknik pengumpulan data, menganalisis kasus negatif, mengadakan sumber check, serta membicarakan dengan orang lain atau rekan sejawat. Terkait dengan hal tersebut di atas maka dapat dirumuskan langkah-langkah yang dilakukan peneliti untuk memperoleh data yang terpercaya melalui :

1. Pengamatan secara terus menerus.

Kegiatan ini dimaksudkan bahwa peneliti berusaha untuk selalu mengamati proses pelaksanaan yang berlangsung. Dengan demikian, peneliti dapat memperhatikan segala kegiatan yang terjadi dengan lebih cermat, aktual, terinci dan mendalam. Di samping itu, peneliti mengumpulkan hal-hal yang bermakna untuk lebih memahami gejala yang terjadi. Pengamatan secara terus menerus ini dilakukan selain untuk menemukan hal-hal yang konsisten, juga dilakukan sebagai upaya untuk memenuhi kriteria reliabilitas data yang diperoleh.

2. Triangulasi data.

Triangulasi adalah teknik pemeriksaan keabsahan data yang memanfaatkan sesuatu yang lain. Di luar data itu untuk keperluan pengecekan atau sebagai pembanding terhadap data itu. Teknik triangulasi yang paling banyak digunakan ialah pemeriksaan melalui sumber lainnya, terdapat empat macam triangulasi yaitu: triangulasi data, triangulasi peneliti, triangulasi metodologis, dan triangulasi teoritis.

3. Membicarakan dengan orang lain (rekan-rekan sejawat yang banyak mengetahui dan memahami masalah yang diteliti).

Teknik ini dilakukan dengan cara mengekspos hasil sementara atau hasil akhir yang diperoleh dalam bentuk diskusi analitik dengan rekan-rekan sejawat. Teknik ini juga mengandung beberapa maksud sebagai salah satu teknik pemeriksaan keabsahan data.

Analisis data dilakukan melalui tiga tahapan yaitu meliputi: reduksi data, penyajian data dan penarikan kesimpulan/ verifikasi. Analisis data dalam penelitian kualitatif merupakan proses penyederhanaan data ke dalam bentuk yang mudah dibaca dan diinterprestasikan. Penelitian kualitatif memandang data sebagai produk dari proses memberikan interprestasi peneliti yang di dalamnya sudah terkandung makna yang mempunyai referensi pada nilai. Dengan demikian data yang dihasilkan dari konstruksi interaksi antara peneliti dan informan.

Kegiatan analisis dalam penelitian kualitatif hanya merupakan rekonstruksi dari konstruksi sebelumnya. Menurut Spradley (2007) penelitian etnografis pada prinsipnya mempunyai satu tujuan tunggal, yakni mengungkapkan sistem makna budaya yang digunakan oleh masyarakat. Analisis domain meliputi penyelidikan terhadap unit-unit pengetahuan budaya yang lebih besar yang disebut domain.

Dalam melakukan jenis analisis ini akan dicari bagaimana kinerja guru berdasarkan masingmasing kompetensinya serta bagaimana pelaksanaan pengembangan keprofesian berkelanjutan di lokasi penelitian.

Analisis komponen digunakan untuk mencari secara sistematis atribut-atribut dan komponen-komponen yang berkaitan dengan permasalahan-permasalahan di atas. Analisis ini melibatkan seluruh proses pencarian, proses memilah-milah, dan mengelompokkan dalam satu dimensi kontras tertentu, sehingga akan ditemukan beberapa kontras yang muncul. Sedangkan analisis tema digunakan untuk menemukan tema-tema yang muncul selama proses penelitian berlangsung baik tema-tema yang bersifat eksplisit maupun insplinsit tentang permasalahanpermasalahan yang berkaitan dengan manajerial Kepala Sekolah.

Untuk menganalisis data dalam masalah ini penulis menggunakan logika deduksi, dengan membandingkan teori yang melatar belakangi permasalahan. Data yang diperoleh dari lapangan akan diolah dengan cara mengumpulkan semua data yang ada. Data yang ada dikelompokkan, diseleksi dan selanjutnya dianalisis. Metode yang digunakan dalam analisis data kualitatif yaitu menganalisis data yang didasarkan pada kualitas data yang digunakan untuk memecahkan permasalahan pokok penelitian, kemudian diuraikan dalam bentuk bahasa deskriptif.

Data yang diperoleh dari penelitian dianalisis dengan menggunakan metode kualitatif, artinya mengelompokkan dan menyeleksi data yang diperoleh dari penelitian berdasarkan kualitas kebenarannya kemudian menggambarkan dan menyimpulkan hasilnya untuk menjawab 
permasalahan yang ada. Penelitian kualitatif prosesnya berlangsung dalam bentuk siklus (Sutopo, 2006) Model analisis interaktif seperti yang dikemukakan Sutopo terlihat seperti gambar berikut :

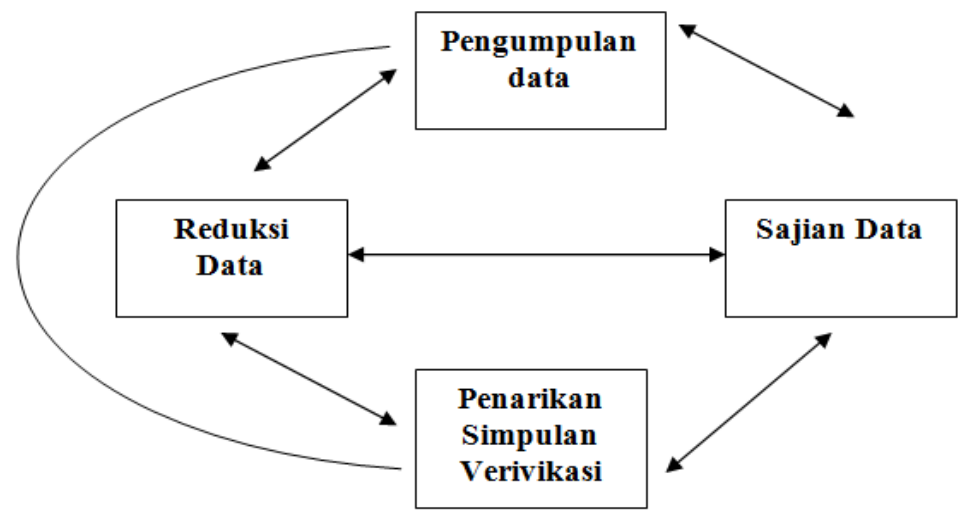

Gambar 3 : Model analisis interaktif

Proses dapat dilihat pada waktu pengumpulan data, penulis selalu membuat reduksi data dan sajian data. Artinya, data yang berupa catatan lapangan yang terdiri dari bagian deskripsi dan refleksinya adalah data yang telah digali dan dicatat. Dari dua bagian data tersebut penulis menyusun rumusan pengertiannya secara singkat, berupa pokok-pokok temuan yang penting dalam arti pemahaman segala peristiwanya yang disebut reduksi data. Kemudian diikuti penyusunan sajian data yang berupa kalimat sistematis dengan suntingan penelitinya supaya makna peristiwanya menjadi lebih jelas dipahami. Reduksi dan sajian data ini harus disusun pada waktu penulis sudah mendapatkan unit kata dari sejumlah unit yang diperlukan dalam penelitian. Pada waktu pengumpulan data sudah berakhir, peneliti mulai melakukan usaha untuk menarik kesimpulan dan verifikasinya berdasarkan semua hal yang terdapat dalam reduksi maupun sajian datanya. Bila kesimpulan dirasa kurang mantap karena kurangnya rumusan dalam reduksi maupun sajian data, maka peneliti wajib kembali melakukan kegiatan pengumpulan data yang sudah terfokus untuk mencari pendukung kesimpulan yang ada dan juga bagi pendalaman. Dalam keadaan ini tampak bahwa penelitian kualitatif prosesnya berlangsung dalam siklus. Biasanya sebelum penulis mengakhiri proses penyusunan penulisan, kegiatan pendalaman data ke lapangan studinya dilakukan untuk menjamin mantapnya hasil penelitian.

Pertama, pada tahap ini akan dilaksanakan klasifikasi dan penyajian data sesuai dengan pokok permasalahan yang diawali dengan pengkodean pada setiap sub pokok permasalahan. Penyajian data dalam penelitian ini dilakukan dalam bentuk uraian singkat, bagan dan hubungan antar kategori. Miles and Hubermen (Sugiono, 2010) menyatakan yang paling sering digunakan dalam penelitian kualitatif adalah teks yang bersifat narasi. Dengan menyajikan data maka memudahkan memahami apa yang terjadi dan rencana selanjutnya berdasarkan apa yang telah dipahami tersebut.

Kedua, Simpulan Dan Verifikasi Data Kesimpulan dalam penelitian ini diperoleh dari data yang telah diolah dan dianalisis pada tahap sebelumnya. dalam penarikan kesimpulan terdapat beberapa cara yang dapat dilakukan yaitu sebagai berikut :

1. Cara induktif, Cara ini merupakan penarikan kesimpulan dari data-data yang bersifat khusus untuk mendapatkan kesimpulan yang bersifat umum.

2. Cara deduktif, Cara ini merupakan cara penarikan kesimpulan dari data-data yang bersifat umum untuk mendapatkan kesimpulan yang bersifat khusus.

3. Cara campuran, Cara ini merupakan cara penarikan kesimpulan yang mana dengan menggabungkan cara induktif dan deduktif, yang keduanya digunakan secara bergantian.

Dalam penelitian ini penulis menggunakan teknik penarikan kesimpulan secara deduktif, yaitu penarikan kesimpulan dari data-data yang bersifat umum untuk mendapatkan kesimpulan yang bersifat khusus. 


\section{HASIL PENELITIAN}

Kepala Sekolah dalam melaksanakan ketrampilan konseptualnya belum maksimal/ kurang sesuai dengan program kerja sekolah. Kepala Sekolah hanya melaksanakan tupoksi sebagai Kepala Sekolah saja, sehingga kurang optimal dalam merelisasikan program kerja sekolah.Seorang Kepala sekolah hendaknya memahami betul apa yang menjadi tugas pokok dan fungsi serta perannya di sekolah. Jika Kepala sekolah mampu memahami tugas dan peran sebagai seorang Kepala sekolah, maka Kepala sekolah akan mudah dalam menjalankan tugasnya terutama berkenaan dengan manajemen sekolah yang akan dikembangkannya. Seperti judul yang diambil oleh peneliti yaitu "Keterampilan Manajerial Kepala Sekolah Dalam Meningkatkan Kinerja Guru SMK Negeri 6 Semarang". Bekal kemampuan dalam memahami kompetensi sebagai seorang Kepala sekolah, ini akan menjadi bekal dalam pelaksanaan kinerja yang harus dilakukannya. Ada banyak kompetensi Kepala sekolah yang setidaknya harus dilaksanakan oleh Kepala sekolah dalam tugasnya seharihari disekolah yang dipimpinnya.

Kepala sekolah dalam melaksanakan tugas dan perannya dalam peningkatan kinerja itu sendiri pada dasarnya merupakan perwujudan pengetahuan, sikap, dan keterampilan yang selaras dengan visi dan misi masing-masing satuan atau jenjang pendidikan berdasarkan kompetensi dasar Kepala sekolah. Di sisi lain, Kepala sekolah juga harus mampu memahami konsep penilaian atau evaluasi. Sebagai pengetahuan bahwa evaluasi merupakan proses pengukuran yang dilakukan terhadap kecenderungan perubahan yang terjadi mengenai suatu fenomena dengan hasil yang cenderung kepada pemaknaan akan perilaku guru yang menunjukkan kinerjanya dalam melaksanakan tugas di sekolah berdasarkan kompetensi guru, menurut Depdiknas mulai dari pembuatan Rencana Pelaksanaan Pembelajaran (RPP) sampai kepada melakukan penilain proses dan hasil belajar.

Kemampuan konseptual, kemanusiaan dan teknik mutlak di miliki oleh Kepala sekolah. Seorang Kepala sekolah pada hakekatnya adalah pemimpin yang menggerakkan, mempengaruhi, memberi motivasi serta mengarahkan orang di dalam organisasi atau lembaga pendidikan untuk mencapai tujuan yang telah ditentukan sebelumnya (Mulyasa, 2004). Kepala sekolah SMK Negeri 6 Semarang dituntut senantiasa meningkatkan efektifitas kinerja. Hasil yang dicapai Kepala sekolah dalam mewujudkan tujuan pendidikan secara efektif dan efisien adalah dengan proses. Dalam proses merencanakan, mengorganisasikan, memimpin dan mengendalikan, belum bisa maksimal dilakukan dinilai dari beberapa hasil wawancara yang dilakukan oleh peneliti, informan memberikan pernyataannya bahwa dalam manajerial Kepala sekolah belum maksimal, sehingga manajerial Kepala sekolah dinilai belum mencapai tujuan yang diharapkan oleh semua warga sekolah, baik dari sumber daya manusia maupun manajemennya.

Kepala Sekolah dalam melaksanakan ketrampilan kemanusiaan dengan baik, serta melaksanakan aturan Dinas pendidikan dengan baik, sehingga mampu melakukan ketrampilan kemanusiaan dengan memberi informasi kepada guru mengenai diklat, workshorp dan pelatihan untuk meningkatkan kinerja guru. Manajerial merupakan proses memimpin dan mempengaruhi orang untuk memahami dan setuju dengan manajemen apa yang perlu dilakukan secara efektif, proses untuk memfasilitasi upaya individu dan kolektif mencapai tujuan bersama. Hal ini menunjukkan bahwa indikator Manajerial Kepala Sekolah yaitu sebagai edukator, manager, administrator, supervisor, leader, inovator dan motivator yang tinggi dapat meningkatkan kinerja guru. Kepala sekolah dalam melaksanakan tugasnya juga berfungsi membantu para guru memahami, memilih dan merumuskan tujuan pendidikan yang akan dicapai, menggerakkan para guru, karyawan, peserta didik dan orang tua peserta didik, serta masyarakat untuk mensukseskan program pendidikan di sekolah, menciptakan sekolah sebagai lingkungan kerja yang harmonis, sehat, dinamis dan nyaman. Dari temuan penelitian bisa dinyatakan bahwa kemampuan keterampilan kemausiaan manajerial Kepala sekolah berjalan dengan baik namun belum optimal.

Kepala Sekolah dalam melaksanakan ketrampilan tehnis dengan baik, yaitu berupaya melengkapi sarana dan prasarana baik Ilmu Tehnologi/ IT, renovasi/ perbaikan alat serta penambahan gedung dan peralatan sekolah untuk semua warga sekolah dalam upaya meninggkatkan kinerja guru.

Keterampilan manajerial Kepala sekolah yang penting dikuasai adalah keterampilan konseptual, kemanusiaan, teknis dan keterampilan manajemen dalam membuat keputusan sebab komunikasi antar warga sekolah terutama guru belum dapat secara nyata direalisasikan di sekolah 
SMK Negeri 6 Semarang. Berdasarkan analisa secara individu dinyatakan bahwa Manajerial Kepala Sekolah memiliki andil yang nyata dalam meningkatkan kinerja guru. Hasil ini memberikan makna bahwa manajerial Kepala Sekolah dapat meningkatkan kinerja guru, artinya semakin efektifitas majerial Kepala Sekolah maka kinerja guru semakin meningkat, sebaliknya majerial Kepala Sekolah kurang efektif maka kinerja guru menurun. Strategi Kepala sekolah dalam meningkatkan kinerja guru yang berkaitan dengan penggunaaan teknologi komputer di sekolah sangat baik dalam proses pembelajaran dan sangat penting sekali sebagai alat bantu yang disebut simulasi bagi para guru atau instruktur dalam menyampaikan materi pembelajaran kepada peserta didik yang sudah diberikan secara maksimal. Dengan menggunakan teknologi komputer maka kinerja guru semakin dimudahkan dan semakin meningkatkan kinerja guru. Adapun kinerja guru smk negeri 6 semarang ialah:

1. Perencanaan pembelajaran, guru harus mampu menyusun bahan ajar dari yang sederhana ke yang kompleks, mudah ke sulit, atau konkrit ke abstrak agar sesuai dengan perencanaan tujuan pembelajaran.

2. Pelaksanaan pembelajaran yang aktif dan kreatif, ketika proses pembelajaran berlangsung guru selalu berperan aktif bersama peserta didik, contoh : Peserta didik diberi tugas, bagaimana mempresentasikan materi dengan power point. Dengan tujuan agar memudahkan pemahaman \& siswa juga trampil dalam IT.

3. Penilaian hasil pembelajaran, Guru menggunakan teknik penilaian (ulangan harian, ulangan mid semester dan ulangan semester) yang disusun untuk mengukur peserta didik baik dalm aspek kognitif, afektif dan psikomotor untuk mengetahui hasil belajar peserta didik.

4. Evaluasi dan tindak lanjut, guru dalam proses pembelajaran harus menindaklanjuti dengan memberikan arahan, kegiatan dan tugas sebagai bagian dari remidi atau pengayaan, contoh: pemberian tugas baik terstruktur maupun non struktur kepada peserta didik.

Strategi Optimalisasi Pengembangan Keterampilan Manajerial Kepala Sekolah dan Peningkatan Kinerja Guru antara lain; Pertama, strategi optimalisasi pengembangan keterampilan manajerial kepala sekolah strategi optimalisasi terkait pengembangan keterampilan manajerial Kepala sekolah yang dilaksanakan oleh Kepala sekolah di SMK Negeri 6 Semaraang adalah dengan mengubah perilaku aatau sikap dalam mengambil kebijakan kearah yang lebih baik sehingga keterampilan konseptual akan lebih terarah disertai dengan kemampuan kemanusiaan yang lebih baik dan kemampuan teknis yang terarah sehingga kinerja guru juga akan semakin baik dan optimal. Kedua, strategi optimalisasi dalam pengembangan kinerja guru difokuskan pada pengembangan sumber daya manusia terhadap peningkatan kinerja guru dengan memberikan kesempatan yang sama untuk mengembangkan diri sesuai dengan profesionalisme para guru di SMK Negeri 6 Semarang.

Keterampilan manajerial Kepala sekolah yang penting dikuasai adalah keterampilan konseptual, kemanusiaan, teknis dan keterampilan manajemen dalam membuat keputusan serta komunikasi antar warga sekolah terutama guru belum dapat secara nyata direalisasikan di sekolah SMK Negeri 6 Semarang. Berdasarkan analisa secara individu dinyatakan bahwa Manajerial Kepala Sekolah memiliki andil yang nyata dalam meningkatkan kinerja guru. Hasil ini memberikan makna bahwa manajerial Kepala Sekolah dapat meningkatkan kinerja guru.

Kinerja guru yang terjadi dilapangan adalah guru dapat menyusun bahan ajar sesuai dengan tujuan perencanaan pembelajaran dikelas.Dalam pelaksanaan pembelajaran dikelas guru berperan aktif dengan melibatkan peserta didik untuk bekerja sama dalam menyiapkan media pembelajaran ketika proses pembelajaran berlangsung di dalam kelas, ini adalah upaya guru dalam memberikan pemahaman yang lebih dan mendalam kepada peserta didik. Kemudian seorang guru juga dapat mengukur kemampuan peserta didiknya untuk mengetahui atau mengukur hasil belajar yang didapat selama waktu tertentu yang biasanya dalam satu semester. Dalam proses pembelajaran berlangsung seorang guru harus mengevaluasi dan menindak lanjuti yang berkaitan dengan remidi atau pengayaan peserta didik selama proses pembelajaran berlangsung.

Strategi yang dilakukan Kepala Sekolah dalam pelaksanaan peningkatan kinerja guru SMK Negeri 6 Semarang dikatakan belum dapat optimal, tetapi kinerja guru tidak hanya berdasarkan pada kemampuan manajerial Kepala sekolah SMK Negeri 6 Semarang. Pada kondisi lembaga pendidikan dengan kemampuan manajerial Kepala sekolah, walaupun kurang berjalan dengan baik 
atau kurang maksimal tetapi tidak berpengaruh terhadap kinerja guru karena profesionalitas yang ditunjukkan guru sangat baik berdasar pada tugas pokok dan fungsi sebagai seorang pendidik di instansi tersebut.

\section{KESIMPULAN DAN SARAN}

Keterampilan konseptual Manajerial yang dilaksanakan Kepala sekolah SMK Negeri 6 Semarang dalam melakukan tugas dan peran sebagai seorang Kepala sekolah masih belum terlaksana dengan baik. Keterampilan kemanusiaaan manajerial Kepala sekolah SMK Negeri 6 Semarang sudah berjalan dengan baik namun belum optimal. Dalam hal keterampilam teknis manajerial Kepala sekolah SMK Negeri 6 Semarang sudah berjalan dengan baik dan optimal.

Perencanaan pembelajaran, kinerja guru dinilai sudah baik tetapi belum optimal. Yang paling menonjol adalah belum dibuatnya Rencana Pelaksanaan Pembelajaran oleh guru yang akan melakukan pembelajaran. Baik atau tidaknya kinerja guru SMK Negeri 6 Semarang, tidakdikarenakan manajerial yang dilakukan Kepala sekolah terutama berkaitan dengan keterampilan konseptual, kemanusiaan dan teknis manajerial Kepala sekolah.

Pelaksanaan Pembelajaran, kinerja guru dinilai sudah berjalan dengan baik. Hal tersebut didukung oleh hasil temuan yang menyatakan sudah digunakannya media pembelajaran berbasis teknologi sebagai salah satu indikasi bahwa pembelajaran berjalan dengan aktif dan inovatif. Berdasarkan analisa secara individu dinyatakan bahwa Kepala Sekolah memiliki andil yang nyata dalam meningkatkan kinerja guru. Hasil ini memberikan makna bahwa manajerial Kepala Sekolah dapat meningkatkan kinerja guru, artinya semakin efektifitas majerial Kepala Sekolah maka kinerja guru semakin meningkat.

Penilaian hasil yang dilakukan oleh guru dalam proses pembelajaran dinilai sudah berjalan dengan baik dan optimal. Guru melaksanakan penilaian terhadap capaiaan peserta didik melalui penilaian langsung dan penilaian jangka panjang. Penilaian langsung dilakukan dengan memberikan pertanyaan-pertanyaan terkait materi yang diberikan pada saat proses pembelajaran sesuai dengan SK/SD dan penilaian jangka panjang yaitu melalui UTS, UAS dan ujian praktek.

Evaluasi dan tindak lanjut yang dilakukan guru dalam proses pembelajaran di nilai berjalan dengan baik dan optimal, hal ini diindikasikan dengan diberikannya arahan terhadap peserta didik dan juga tugas baik terstruktur maupun tidak terstruktur untuk peserta didik yang membutuhkan perbaikan atau remedial yaitu khusus peserta didik yang nilai Kriteria Ketuntasan Minimalnya (KKM) belum terlampaui.

Strategi yang dilakukan Kepala Sekolah dalam pelaksanaan peningkatan kinerja guru SMK Negeri 6 Semarang dapat optimal, Karena kinerja guru tidak hanya ditentukan oleh keterampilan manajerial Kepala sekolah, pada kondisi lembaga pendidikan dengan keterampilan manajerial Kepala sekolah walaupun kurang berjalan baik, tetapi tidak berpengaruh terhadap kinerja guru karena profesionalitas yang ditunjukkan guru sangat baik berdasar pada tugas pokok dan fungsi sebagai pendidik. Kinerja Kepala sekolah dapat dipahami sebagai upaya yang harus dilakukan oleh Kepala sekolah dalam melaksanakan tugas dan perannya sebagai seorang Kepala sekolah. Kinerja itu sendiri pada dasarnya merupakan perwujudan pengetahuan, sikap, dan keterampilan yang selaras dengan visi dan misi masing-masing satuan atau jenjang pendidikan berdasarkan kompetensi dasar Kepala sekolah.

Dari hasil analisis dan pembahasan pada penelitian ini, penulis merekomendasikan manajerial Kepala Sekolah dapat berupaya menjalankan tugas dan peran Kepala sekolah dengan baik. Dan meningkatkan kemampuan manajerial yang optimal agar kinerja guru SMK Negeri 6 Semarang dapat meningkat.Kinerja guru SMK Negeri 6 Semarang sudah cukup baik sesuai dengan profesionalitas seorang pendidik, serta tugas pokok dan fungsi guru juga berjalan baik, walaupun Kepala sekolah kurang optimal dalam memanajerial. Ketrampilan manajerial Kepala Sekolah seharusnya selalu melakukan pola komunikasi organisasi yang baik dengan guru maupun karyawan, pengawas dan komite serta warga sekolah, agar dapat mengetahui aspirasi dan masukan-masukan yang dimiliki oleh mereka, sehingga tidak terjadi penurunan kemampuan kerja dan kinerja guru SMK Negeri 6 Semarang. 


\section{DAFTAR PUSTAKA}

Arikunto. 2002. Prosedur Penilaian Suatu Pendekatan Praktek. Jakarta: Bumi Aksara.

Aswar, Saifuddin. 2008. Sikap Manusia, Teori dan Pengukurannya. Yogjakarta : Pustaka Pelajar

Atep Yogaswara, 2010, "Kontribusi Manajerial Kepala Sekolah dan Sistem Informasi Kepegawaian Terhadap Kinerja Mengajar Guru SMP Negeri Purwakarta”. Semarang: Program Pascasarjana IKIP Veteran Semarang.

Bafadal. 2005. Peningkatan Profesional Guru dalam kerangka Menajemen Peningkatan Mutu Berbasis Sekolah. Jakarta: Bumi Aksara.

Depdiknas. 2001. Kamus Besar Bahasa Indonesia, Jakarta : Balai Pustaka.

Deddy Krisdiyanto, 2008, "Kontribusi keterampilan manajerial Kepala Sekolah, supervise klinis dan kinerja guru terhadap hasil belajar ilmu pengetahuan alam siswa kelas V Sekolah Dasar Negeri se-Kota Semarang tahun 2007/2008’Tesis. Semarang: Program Pascasarjana Sekolah Tinggi Ilmu Ekonomi dan Pariwisata Semarang

Direktorat Tenaga Kependidikan Direktorat Jenderal PMPTK Depdiknas. 2008. Penilaian Kinerja Guru.Jakarta : Balai Pustaka.

Gatot Kuncoro, 2008, "Peran Kepala Sekolah dalam Implementasi Manajemen Berbasis Sekolah di MTs Negeri Piyungan Yogyakarta". Tesis. Yogyakarta. Universitas Muhammadiyah Yogyakarta

Gunarso, Singgih. 2005 Psikologi Untuk Membimbing. Jakarta : Gunung Mulia

Hasibuan. 2007. Manajemen Sumber Daya Manusia (Edisi Refisi). Jakarta: Bumi Aksara.

Kemendiknas. 2010.Pedoman Pelaksanaan Penilaian Kinerja Guru. Jakarta. Direktorat Jenderal Peningkatan Mutu Pendidik dan Tenaga Kependidikan.

Kusdiantoro, Agus. 2013. "Pengaruh Sertifikasi dan Kompetensi Terhadap Profesionalisme Serta Dampaknya Pada Kinerja Guru Tersertifikasi Pada SMA NegeriSeKecamatan Pati Kabupaten Pati". Tesis. Semarang: Program Pascasarjana Sekolah Tinggi Ilmu Ekonomi dan Pariwisata Semarang.

Mulyasa.2007. Menjadi Guru Profesional. Bandung :PT. Remaja Rosdakarya

NurtrianoAgos P, 2010, "Strategi Mengembangkan Kompetensi Manajerial Kepala Sekolah". Tesis. Surakarta. Program Pascasarjana Universitas Negeri Surakarta.

Peraturan Menteri Pendayagunaan Aparatur Negara dan Reformasi Birokrasi Nomor 16 Tahun 2009 tentang Jabatan Fungsional Guru.

Peraturan Menteri Pendidikan Nasional Nomor 35 Tahun 2010 tentang Penilaian Kinerja Guru.

Peraturan Menteri Pendidikan Nasional Nomor 41 Tahun 2007 tentang Standar Proses.

Priansa. 2013. Kinerja ddan Profesionalisme Kepala Sekolah. Bandung : Alfabeta

Prima, Nanang dan Tito Sukanto. 2013. Pengembangan Profesi Guru. Bandung : Rosda

Rivai, Veithzal. 2006. Manajemen Sumber Daya Manusia. Rajawali Pers.

Sagala. 2009. Kemampuan Profesi guru dan tenaga kependidikan. Bandung : Alfabeta

Simanjuntak. 2005. Manajemen dan Evaluasi Kinerja (Edisi 3 ). Lembaga Penerbit FEUI

Sugiyono. 2010. Metode Penelitian Kuantitatif Kualitatif dan $R \&$ D. Bandung: Alfabeta.

Suharso, Yohanes. 2013. "Peran dan Tanggung Jawab Guru Sebagai Tenaga Profesional”. Tesis. Semarang: Program Pascasarjana IKIP Veteran Semarang

Suwanto. 2013. "Pengaruh Motivasi Guru dan Kompetensi Profesional Guru Terhadap Kinerja Guru Dengan Mediasi Supervisi Kepala Sekolah di SD Negeri Dabin III Kecamatan Mranggen Kabupaten Demak”. Tesis. Semarang: Program Pascasarjana Sekolah Tinggi Ilmu Ekonomi dan Pariwisata Semarang.

Undang-undang Republik Indonesia Nomor 14 Tahun 2005 tentang Guru dan Dosen.

Undang-undang Republik Indonesia Nomor 20 Tahun 2003 tentang Sistem Pendidikan Nasional. 2008. Jakarta: PT Gramedia Pustaka Utama

Usman Uzer. 2006. Menjadi Guru Profesional. Bandung: Rosdakarya. 